\title{
THE EXCRETION OF INTRAVENOUSLY INJECTED BILIRUBIN AS A TEST OF LIVER FUNCTION
}

\author{
By GEORGE A. HARROP, JR., AND E. S. GUZMAN BARRON
}

(From the Chemical Division of the Medical Clinic, Johns Hopkins University and Hospital, Baltimore)

(Received for publication July 31, 1930)

The liver plays such an important rôle in the animal body that the study of methods for testing its functional ability has attracted and still attracts considerable interest. As this gland is believed to be the site of internal as well as of external secretions, it is probable that dissociated functional disturbances may arise when it is acted upon by an injurious agent. At least theoretically, therefore, an adequate test for liver function ought to include the study of all of its multiple activities. It is likely, however, that some of these functions are more susceptible to the action of noxious agents and are readily damaged when other functions are still unimpaired. Such appears to be true as regards the ability of the liver to excrete bilirubin. The important place which the Van den Bergh reaction and the determination of bilirubinemia have taken in the study of liver disease indicates the trend of current opinion.

It is, however, well recognized that there are conditions of mild liver injury where the bilirubinemia is not increased, either because the liver cells are still able to excrete the normally circulating bilirubin or because there is a diminished production of the pigment. In either case the insufficiency of the liver might be demonstrated by injecting an additional amount of the pigment and studying the rate of its excretion. Working on this theory, Barron and Rich (1) have recently been engaged in the study of bilirubin excretion in dogs with the intention of applying the method later to clinical use. Meantime reports have been published in Germany by Von Bergmann (2) and his associate, Eilbott (3) who have applied the bilirubin excretory power of the liver to the study of a variety of hepatic disorders, particularly cirrhosis, chronic passive congestion of the liver, cholecysti- 
tis and miscellaneous cases of jaundice. These authors injected 70 mgm. of bilirubin dissolved in $10 \mathrm{cc}$. of 5 per cent $\mathrm{NaOH}$ estimating the blood concentration at measured time intervals thereafter.

\section{THEORETICAL BASIS FOR THE BILIRUBIN EXCRETION TEST}

From the considerable literature devoted to the problem of the site of bilirubin formation it can be concluded that there is no evidence that the polygonal liver cells are concerned with the formation of bilirubin. In all probability the cells of the recticulo-endothelial system are actively concerned in the formation of the pigment through hydrolysis of the blood hemoglobin and possibly of related pigments.

The site of bilirubin excretion has been less subject to discussion. As early as 1874, Tarchanoff (4) studied the excretion of intravenously injected bilirubin in dogs, determining the pigment in the bile and urine by means of fistulas of the common bile duct and ureters. He reported that all of the injected bilirubin was found in the bile and none in the urine. These observations were confirmed by Vossius (5) in the same animal and by Beckmann (6) in rabbits. They used the Gmelin test for detecting bilirubin in the urine. These observations are correct in their essential conclusions. The liver of the dog possesses such an enormous ability to excrete bilirubin that even though there is no renal threshold for bilirubin, the amount secreted through the kidneys is at its maximum only one per cent of the injected bilirubin. In man the kidney does not take any part in the excretion of the pigment, under the conditions of our experiments, since we have studied only individuals with blood serum showing an indirect Van den Bergh reaction. Although the bilirubin solution, which is injected intravenously, gives a direct Van den Bergh reaction, as soon as it enters the blood stream it is adsorbed by the proteins of the blood serum and the Van den Bergh reaction becomes indirect, exactly in the same manner as occurs when a solution of bilirubin is added in vitro to serum (Harrop and Barron (7)). It is well known that bilirubin giving the indirect Van den Bergh reaction is not excreted through the kidneys. It can be argued that the injected bilirubin may be phagocyted by the cells of the reticulo-endothelial system in the same manner as occurs when foreign pigments are injected into the blood stream. The ob- 
servations of Kanner (8) are against such an assumption. Studying systematically the reticulo-endothelial system in different types of jaundice, Kanner (8) found that only in cases of complete obstructive jaundice was there any storage of bilirubin within the Kupfer cells; in conditions of partial obstructive jaundice and non-obstructive jaundice he never found evidence of bilirubin storage whether in the Kupfer cells or at any other place in the reticulo-endothelial system.

The studies which have been briefly summarized above indicate that injected bilirubin is not excreted through the kidneys, that it is not retained by the cells of the reticulo-endothelial system; and that it is totally excreted by the liver. The rate of excretion of bilirubin injected intravenously may therefore be employed as a rational test for liver function.

\section{SOLUBILITY OF BILIRUBIN}

It is well known that bilirubin is soluble in aqueous solvents, only when they are highly alkaline. Kerppola and Leikola (9) have studied the solubility of bilirubin at different hydrion concentrations, mixing solutions of bilirubin in chloroform with various buffers. They found that the pigment remained in the chloroform solvent from $\mathrm{pH}$ 0.0 to $\mathrm{pH} 6.5$; that it is entirely dissolved in the buffer at $\mathrm{pH} 12$ to $\mathrm{pH}$ 14 and that from $\mathrm{pH} 7$ to $\mathrm{pH} 11.5$ some of the pigment remains dissolved in choroform while another portion goes into the buffer. We have studied the solubility of bilirubin in aqueous solvents at different hydrion concentrations, using in all the experiments the same bilirubin concentration, namely, 0.4 per cent. Bilirubin at such concentration can be kept entirely in solution when using solvents having a $\mathrm{pH}$ of about 11.0 provided the temperature of the solvent has been previously raised to $80^{\circ} \mathrm{C}$. Once the bilirubin is in solution it can be kept dissolved until the $\mathrm{pH}$ is lowered to 9.4 by addition of appropriate buffers.

\section{TECHNIQUE OF THE BILIRUBIN EXCRETION TEST}

The technique which we have employed is as follows: The bilirubin used was obtained from the Eastman Kodak Company and was used without previous sterilization at a concentration of $1 \mathrm{mgm}$. per 
kilogram of body weight. 1 It was dissolved in $15 \mathrm{cc}$. of $0.5 \mathrm{M} \mathrm{Na}_{2} \mathrm{CO}_{3}$ previously boiled, after the solution had cooled to about $80^{\circ} \mathrm{C}$. The final $\mathrm{pH}$ of the solution at $20^{\circ} \mathrm{C}$. was 11.08 (as determined by the hydrogen electrode). A control sample of blood was taken before the injection. After the injection, blood was taken at the following intervals: 5 minutes, 30 minutes, 2 hours and 4 hours. The blood was received in test tubes containing 3 drops of 10 per cent of potassium oxalate which was previously dried. It was then kept in the dark in the ice box until the final collection was completed.

Determination of bilirubin. In a previous review of the different methods used for the estimation of blood bilirubin (Harrop and Barron (7)) it has been stated that the Van den Bergh method is the most reliable and accurate of the clinical methods. When determining small amounts of the pigment however the colorimetric readings are extremely uncertain and unreliable. We have therefore used Ernst and Förster's method (10) which is performed essentially as follows: The plasma is precipitated by acetone, which is used at different concentrations according to the amount of bilirubin present in the plasma. After shaking it is centrifuged and filtered, and the filtrate read at once in a colorimeter against a standard composed of potassium dichromate, 1 to 6000 , which had previously been standardized against a solution of bilirubin. By this method one determines both the bilirubin and the unknown amount of lipochromes present in the blood plasma. It seems safe to assume however that there can be no change in the lipochrome concentration during the performance of the test. The error therefore remains constant and is removed from consideration by subtracting the figure found as the bilirubin value in the control sample from the figures obtained from the other samples. Van den Bergh has shown (11) that bilirubin giving an indirect reaction is not adsorbed by the alcoholic precipitate of the serum proteins; the same thing applies to the acetone precipitate. As the Van den Bergh reaction in all the samples is indirect (provided the original

1 We have recently had difficulty in obtaining bilirubin for injection from the Eastman Kodak Co. owing to temporary difficulties in their process of purification which they state will shortly be overcome. Meantime, Dr. L. J. Soffer has employed Bilirubin "Homburg," obtainable from Chemisch-Pharmazeut A. G., Bad Homburg, Germany, with equally satisfactory results, in this clinic. 
control sample is indirect) there is no loss of bilirubin due to the precipitation of proteins.

The rate of bilirubin excretion was plotted according to Von Bergmann and Eilbott's method, i.e., the bilirubin content of the sample taken five minutes after the injection minus that of the control sample, was considered as containing 100 per cent of the injected pigment. The percentage retention of bilirubin in the other blood samples was then calculated after previous subtraction of the bilirubin contained in the control.

THE EXCRETION OF BILIRUBIN BY THE LIVER IN NORMAL INDIVIDUALS

When bilirubin is injected intravenously into normal individuals at the concentration given above, i.e., $1 \mathrm{mgm}$. per kilogram of body weight, it is totally excreted in from 2 to 4 hours. Table 1 and figure 1 (dotted lines) show the rate of excretion of the pigment in normal persons. As is there shown, in the majority of cases the bilirubin was totally excreted within 2 to 3 hours after the injection. In some cases at the end of 3 hours, a slight retention still existed, but in these cases all the pigment had been excreted at the end of 4 hours. We may therefore conclude that 4 hours is the maximum limit for the total excretion of bilirubin in normal individuals. Whenever bilirubin retention is still present at the end of 4 hours we may consider that the power of the liver to excrete the pigment has been impaired.

THE APPLICATION OF THE BILIRUBIN EXCRETION TEST TO PATHOLOGICAL CONDITIONS

Our interest in the clinical application of this liver function test has been confined to cases of slight liver insufficiency which could not be detected by either the Van den Bergh test or by the use of the levulose or bromsulphalein tests. The introduction of an additional test for hepatic function is scarcely justified unless it yields information to the clinician which is not otherwise obtainable.

An interesting condition in which liver damage may be possible but has never as yet been clearly demonstrated is severe anemia. Rich and Resnik (12) observed that in pernicious anemia, as well as in experimentally produced anemias, the cells about the efferent veins of each liver lobule may be damaged in a manner often indistinguishable 
from that accompanying chronic passive congestion. They advanced the suggestion that the damage to the liver cells may be due to poor oxygenation. It was of interest to study the bilirubin excretory power of the liver in such cases. There is in pernicious anemia a hyperbilirubinemia which is considered by many authors as of hemolytic nature and due solely to the increased red cell destruction. Secondary anemias usually show a hypobilirubinemia. The present test has been

TABLE 1

The serum bilirubin retention in individuals without demonstrable liver injury

\begin{tabular}{|c|c|c|c|c|c|}
\hline \multirow{2}{*}{$\begin{array}{c}\text { Case } \\
\text { number }\end{array}$} & \multicolumn{4}{|c|}{ * Per cent of bilirubin retention in blood serum } & \multirow{2}{*}{ Diagnosis and remarks } \\
\hline & 30 minutes & 2 hours & 3 hours & 4 hours & \\
\hline 1 & 35.0 & 0.0 & & & $\begin{array}{l}\text { Convalescent from rheumatic } \\
\text { fever normal temperature } 18 \\
\text { days }\end{array}$ \\
\hline 2 & 32.8 & 0.0 & & & Gastritis \\
\hline 3 & 16.5 & 6.4 & 0.0 & & $\begin{array}{l}\text { Recovered from lobar pneu- } \\
\text { monia normal temperature for } \\
3 \text { weeks }\end{array}$ \\
\hline 4 & 38.7 & 9.0 & 0.0 & & Neurasthenia \\
\hline 5 & 36.5 & 9.6 & 0.0 & & Sulphemoglobinemia \\
\hline 6 & 28.2 & 8.6 & 0.0 & & Sulphemoglobinemia \\
\hline 7 & 41.0 & 6.0 & 0.0 & & Chronic arthritis \\
\hline 8 & 36.0 & 4.0 & 0.0 & & Normal \\
\hline 9 & 45.5 & 26.8 & 0.0 & & Polycythemia vera \\
\hline 10 & 31.7 & 19.0 & 2.7 & 0.0 & Polycythemia vera \\
\hline 11 & 53.0 & 9.0 & 4.0 & 0.0 & Hernia \\
\hline 12 & 60.0 & 11.2 & 5.0 & 0.0 & Gastric ulcer \\
\hline
\end{tabular}

Bromsulphalein and Levulose Tolerance Tests showed normal function in all of these cases.

* Percentage calculated on basis of amount present in blood 4 minutes after injection considered as 100 per cent.

used clinically on five patients with primary anemia and two patients with secondary anemia. In all of these cases other tests for hepatic function were also performed: (a) The Van den Bergh reaction, which was always indirect; $(b)$ the quantitative estimation of bilirubinemia which never was beyond $1 \mathrm{mgm}$. per cent; $(c)$ the levulose tolerance and bromsulphalein tests which in all of these cases yielded no evidence of liver damage. Table 2 and figure 1 show that in all, except 
one case of pernicious anemia, there was a definite retention of bilirubin at the end of four hours, indicating the presence of a functional disturbance of the liver.

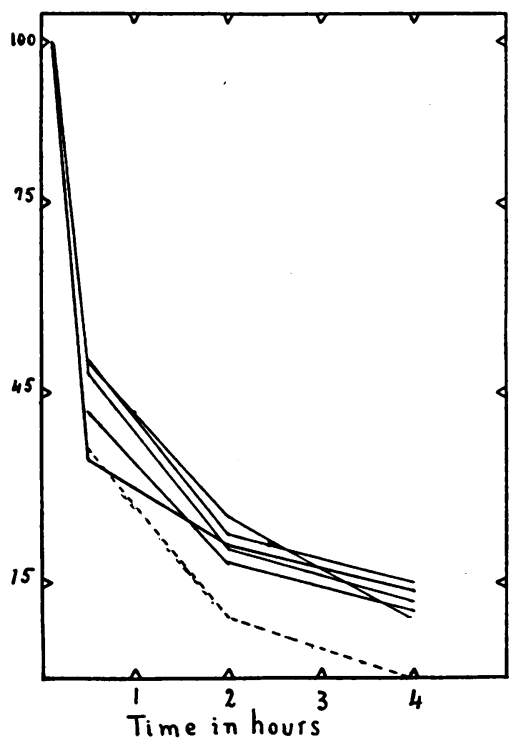

Fig. 1

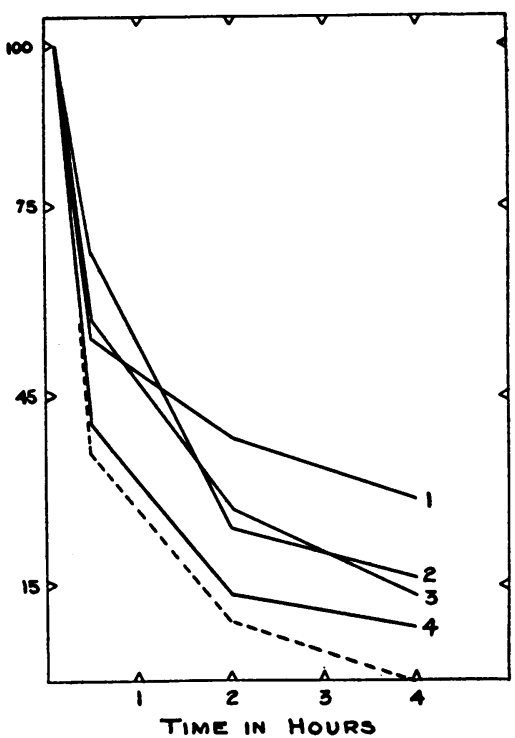

FIG. 2

Fig. 1. Bifirubin Excretion Curves in Cases of Chronic Anemia

Ordinates, per cent of bilirubin excreted. Abscissa, time in hours. Dotted line-normal curve. Full lines-cases of anemia.

Fig. 2. Bilirubin Excretion Curves in Miscellaneous Cases of Liver DAMAGE

Ordinates, per cent of bilirubin excreted. Abscissa, time in hours. 1, typhoid fever, presumably slight infectious hepatitis; 2 , cirrhosis of the liver; 3 , postarsphenamine jaundice (Clinically recovered); 4, carcinoma of the liver. Dotted line-normal curve.

In table 3 are given the results obtained in a number of pathological conditions, including cirrhosis of the liver, acute infectious disease in which liver damage may be suspected, and post-arsphenamine jaundice some months after clinical recovery. The demonstrations of definite liver damage in typhoid and other fevers, without clinical 


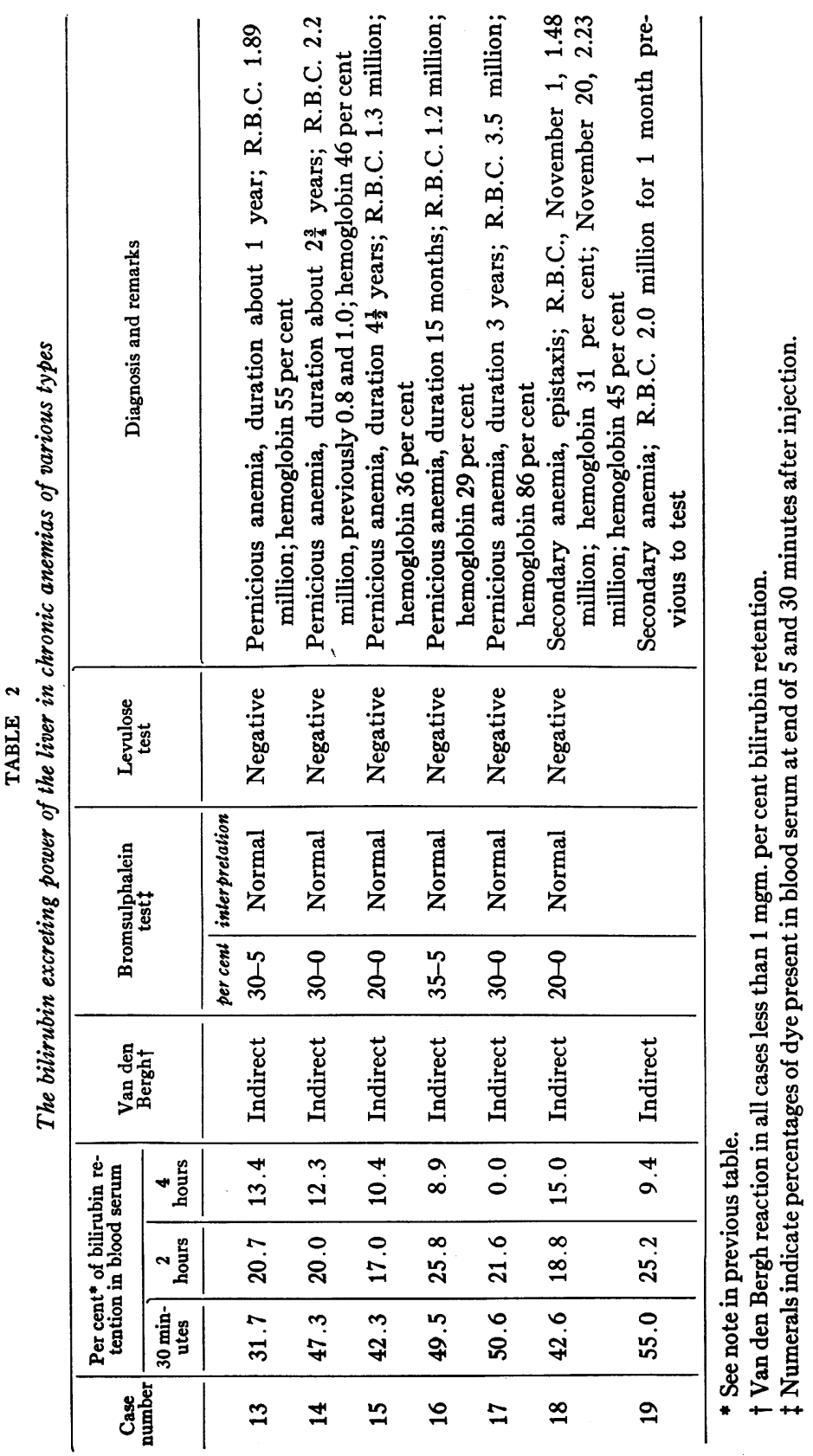


G. A. HARROP, JR., AND E. S. G. BARRON

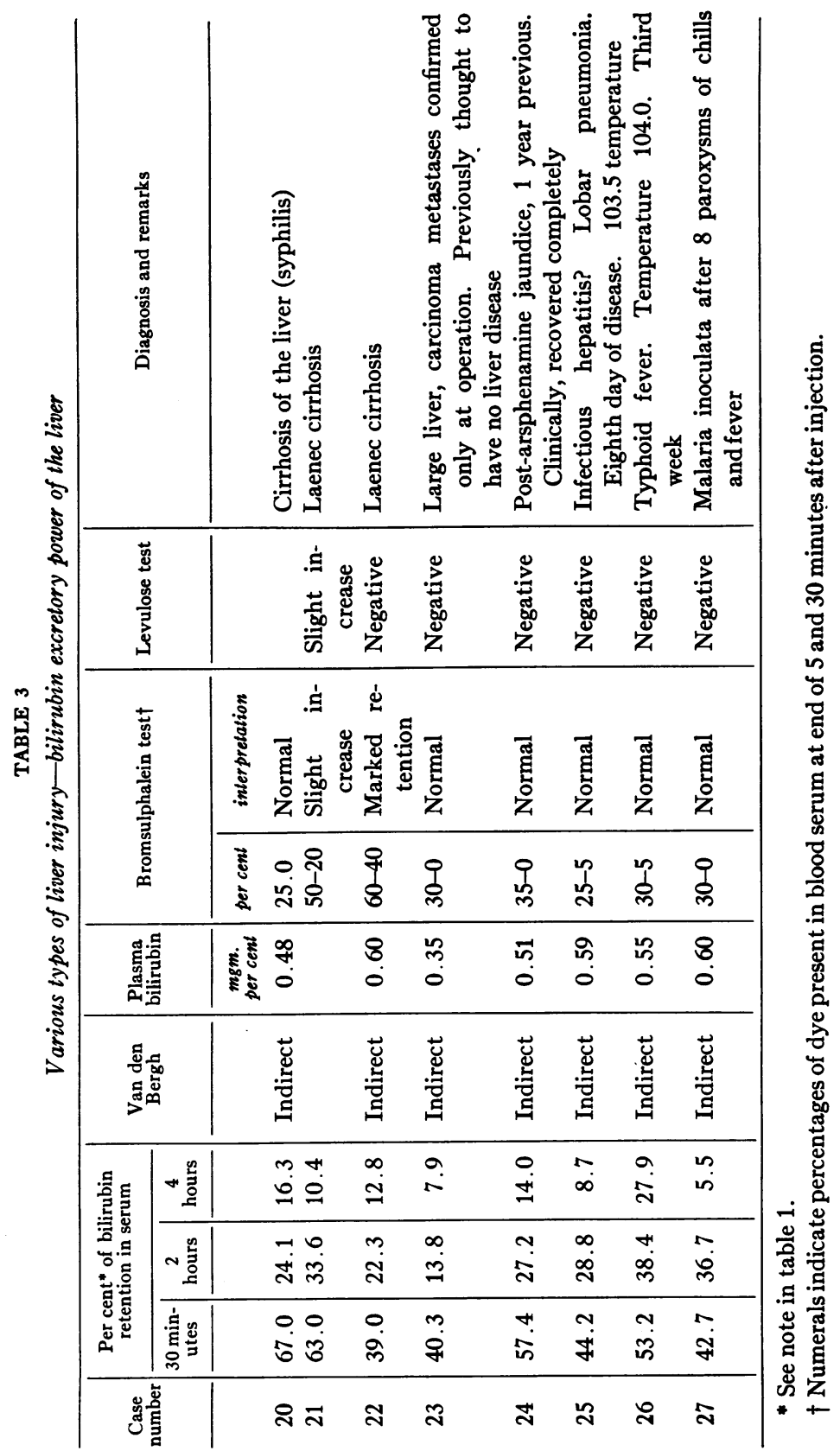

THE JOURNAL OF CLINICAC INVEBTIGATION, VOL. IX, NO: 4 
evidences of jaundice or of any other functional disturbance is of considerable interest, as is that of continued liver disturbance in postarsphenamine jaundice long after clinical recovery has apparently taken place. It seems indeed possible that such damage may be permanent after infections or intoxications in which at the time, or subsequently, it is entirely unsuspected, and that a systematic study of such mild degrees of liver damage may explain many liver disorders in later life, the etiology of which is quite obscure at present.

We may call attention to the fact that the bilirubin excretion was normal in the two cases of polycythemia vera studied (cases 9 and 10). This has been a matter of surprise to us and we are not prepared to state, as a general rule, that no retention occurs in this disease without further study. In both of these cases, which we have followed for several years, due to phenyl hydrazine and x-ray therapy, the blood counts were not elevated, and at the same time of these bilirubin studies the liver in neither individual was enlarged on physical examination. Splenomegaly was present in both patients.

\section{SUMMARY AND CONCLUSIONS}

The introduction by Van den Bergh of a method of estimating blood bilirubin and his discovery of the difference in behavior of serum bilirubin towards the Ehrlich diazo-reagent contributed greatly to our knowledge of liver pathology. Cases of liver damage could easily be followed in their evolution by the use of these simple methods. But there still remain cases of liver insufficiency where there is no retention of the pigment because the liver, although damaged, can still excrete normally the circulating bilirubin. It is logical to assume that these slight liver insufficiences may be recognized by increasing the blood bilirubin concentration and testing the power of the liver to excrete this artificially produced hyperbilirubinemia. The experiments above reported prove that such is the case. We have chosen for our studies selected cases of slight liver injury where all the commonly used methods failed to give evidence of damage of the liver and in all these cases we have found that it was possible to recognize an insufficiencyof the liver as shown by delayed bilirubin excretion. It seems justified to conclude that study of the bilirubin excretory power of the liver is the most delicate method so far proposed for testing the functional capacity of this organ. 


\section{BIBLIOGRAPHY}

1. Barron, E. S., Guzmann, and Rich, A. R., Unpublished data.

2. Von Bergmann, G., Klin. Wchnschr., 1927, vi, 776. Zur funktionellen Pathologie der Leber insbesondere der Alkohol-Ätiologie der Cirrhose.

3. Eilbott, W., Ztschr. f. Klin. Med., 1927, cvi, 529. Funktionsprüfung der Leber mittels Bilirubinbelastung. (Mit 7 Textabbuldungen.)

4. Tarchanoff, J. F., Pflügers Arch. f. ges. Physiol., 1874, ix, 53. Ueber die Bildung von Gallenpigment aus Blutfarbstoff im Thierkörper.

5. Vossius, Inaug. Diss. Giesse, 1879. Über quantitative spektralanalytische Bestimmungen des Bilirubins in der Galle.

6. Beckmann, Quoted by Eppinger. Die Pathogenese des Ikterus, Berlin, 1920.

7. Harrop, G. A., Jr., and Barron, E. S. G., Trans. Assoc. Am. Phys., 1929, xliv, 143. The Nature of the Van den Bergh Reaction.

8. Kanner, O., Klin. Wchnschr., 1924, iii, 108. Über die Rolle der Kupfferschen Sternzellen beim Ikterus.

9. Kerppola, W., and Leikola, E., Skandin. Arch. f. Physiol., 1928, liv, 120. Zur Chemie des Bilirubins. I. Das Verhalten des Bilirubin zu verschiedenen Lösungsmitteln bei wechselnder Wasserstoffionenkonzentration.

10. Ernst, Z., and Förster, J., Klin. Wchnschr., 1924, iii, 2386. UUber die Bestimmung des Blutbilirubins.

11. Van den Bergh, A. A. Hijmans, Der Gallenfarbstoff im Blute, Leipzig, 1918.

12. Rich, A. R., and Resnik, W. H., Bull. Johns Hopkins Hospital, 1926, xxxviii, 75. On the Mechanism of the Jaundice Following Pulmonary Infarction in Patients with Heart Failure. 